\title{
PENINGKATAN SADAR HUKUM BERBANGSA DAN BERNEGARA DITINJAU DARI AJARAN AHLUSUNNAH WAL JAMA'AH
}

\author{
Muhammad Zainuddin, Nurul Nisah \\ Fakultas Tarbiyah dan Ilmu Keguruan, Universitas Islam Nahdlatul Ulama, Jepara \\ $\underline{\text { mzyahud@gmail.com }}$
}

\begin{abstract}
Abstrak
Tujuan penelitian ini untuk mengkaji upaya peningkatan kesadaran hukum dalam berbangsa dan bernegara ditinjau dari ajaran Ahlusunnah Wal Jama'ah. Negara Indonesia adalah negara hukum, hal ini dinyatakan tegas dalam Pasal 1 ayat (3) UUD 1945, akan tetapi masih banyak warga negara yang belum sadar akan hukum. Upaya internalisasi nilai hukum dalam diri masyarakat dapat ditanamkan melalui pendidian hukum dalam pendidikan kewarganegaraan, dalam perkembangannya ajaran Ahlusunnah Wal Jama'ah secara turun temurun menjadi landasan hukum dalam beribadah dan mengatur seluruh ruang lingkup kehidupan masyarakat muslim, bagi Nahdlatul Ulama' Pancasila dan Undang-Undang Dasar 1945 dirumusan sebagai landasan bertindak karena berisikan ketuhanan, kebangsaa serta sikap adil sesama manusia. Metode yang digunakan dalam penelitian ini mengunakan pendekatan yuridis sosiologis dengan teknik pengumpulan data studi kepustakaan. Ahlusunnah Wal Jama'ah menjadikan negara sebagai sarana atau wadah untuk menjamin, melayani, melindungi dan mengarahkan seluruh yang ada di dalamnya, baik warga negara, keutuhan wilayah, termasuk keseluruhan harta kekayaan yang terdapat dalam wilayah negara tersebut dan fungsi dari peningkatan kesadaran hukum adalah sebagai langkah pencegahan, langkah korektif, langkah pemeliharaan dan fungsi pengembangan.
\end{abstract}

Kata kunci: Sadar Hukum; Bernegara; Ahlusunnah Wal Jama'ah 
p-ISSN : 2541-2345, e-ISSN : 2580-8842

Muhammad Zainuddin, Nurul Nisah

\title{
IMPROVING LEGAL CONSCIOUSNESS NATION AND STATE REVIEWED FROM THE TEACHING OF AHLUSUNNAH WAL JAMA'AH
}

\begin{abstract}
The state of Indonesia is a state of law, this is stated expressly in Article 1 paragraph (3) of the 1945 Constitution, but there are still many citizens who are not aware of the law. Efforts to internalize the value of law in the community can be instilled through legal education in citizenship education, in its development the teachings of Ahlusunnah Wal Jama'ah have been hereditary into a legal basis in worshiping and regulating the entire scope of life of Muslim communities, for Nahdlatul Ulama 'Pancasila and the Law The foundation of 1945 was formulated as a basis for acting because it contained a divinity, a nationality and a fair attitude towards fellow human beings. The method used in this study uses a Sociological Juridical approach with data collection techniques in the literature. Ahlusunnah Wal Jama'ah makes the state as a means or a place to guarantee, serve, protect and direct all that is in it, both citizens, territorial integrity, including the entire assets contained within the country's territory and the function of increasing legal awareness is as preventive steps, corrective steps, maintenance steps and development functions.
\end{abstract}

Keywords: Legal Awareness; National; State Ahlusunnah Wal Jama'ah 


\section{PENDAHULUAN}

\section{A. Latar Belakang}

Negara Indonesia adalah negara hukum, sebagaimana yang tercantum dalam UUD 1945 Pasal 1 Ayat (3) yang menyatakan bahwa "Negara Indonesia adalah negara hukum”. Hal ini menjadikan posisi negara Indonesia yang dalam seluruh tatanan kehidupan bermasyarakat, berbangsa dan bernegara harus berdasarkan pada seluruh peraturan hukum yang berlaku. Hukum yang berlaku ini bersifat memaksa dan menyeluruh kepada seluruh elemen masyarakat yang seharusnya dapat mengarahkan masyarakat menjadi taat hukum. Namun jika dilihat permasalahan yang sedang terjadi ini membuktikan bahwa kesadaran masyarakat yang taat terhadap hukum ini masih rendah. Tanpa munculnya kesediaan warga dalam mengikuti perintah untuk dikerjakan dengan sukarela, tidak akan ada usaha untuk merealisasikan bekerjanya hukum dalam kehidupan bermasyarakat akan dapat terwujud seperti yang diharapkan.

Sesuai dengan salah satu pengertian negara hukum, dimana setiap tindakan penyelenggaraan negara harus dilakukan berdasarkan dalam koridor hukum, maka yang harus mengawal hukum adalah segenap penyelenggara negara dan seluruh warga negara dengan cara menjalankan hak dan kewajiban konstitusional. Apabila setiap pejabat dan aparat penyelenggara negara telah memahami UUD 1945 serta melaksanakan wewenangnya berdasarkan hukum, kebijakan dan tindakan yang dihasilkan adalah bentuk pelaksanaan UUD $1945^{1}$.

Pelaksanaan pembangunan hukum harus dilakukan secara komprehensif mencakup substansi hukum, kelembagaan hukum dan budaya hukum serta dibarengi dengan penegakan hukum secara tegas dan konsisten dengan tetap menjunjung tinggi hak asasi manusia, sehingga aktualisasi fungsi hukum sebagai sarana pembaharuan dan pembangunan, instrumen penyelesaian masalah secara

${ }^{1}$ Atang Hermawan Usman, "Kesadaran Hukum Masyarakat dan Pemerintah Sebagai Faktor Tegaknya Negara Hukum di Indonesia”, Jurnal Wawasan Hukum 30(1), 2014, hal 27. DOI: http://dx.doi.org/10.25072/jwy.v30i1.74 
adil serta sebagai pengatur perilaku masyarakat untuk menghormati hukum dapat tercapai ${ }^{2}$.

Kondisi internal warga masyarakat baik yang bersifat psikologis maupun kultural tidak dapat diabaikan. Manusia dalam aspek psikologisnya memerlukan pedoman dan dorongan batin dalam kehidupannya. Dorongan batin ini diperoleh dari faktor spiritual yang mempengaruhi individu, baik agama dan ajaran yang dianutnya. Di Indonesia terdapat beberapa agama yang diikuti dengan banyaknya paham atau ajaran agama yang berkembang, Secara mayoritas penduduk Indonesia menganut agama islam dan lebih dominan pada ajaran Ahlusunnah Wal Jama'ah.

Memanifestasikan prinsip dan karakter Aswaja pada segala bidang ajaran agama islam, harus selalu dipertahankan, dipelihara dan dikembangkan sebaikbaiknya agar keberadaannya jelas dan tidak mudah terpenggaruh serta tergeserkan oleh aliran-aliran. Apalagi pada zaman modern saat ini yang sudah sangat banyak ditemukan berbagai persoalan kemerosotan moral. Sehingga perlu adanya gerakan revitalisasi kembali karakter-karakter mulia untuk membangun bangsa yang mulia ${ }^{3}$.

Pendidikan yang mengembangkan ajaran Ahlussunnah Wal Jama'ah memiliki potensi yang besar untuk menjadi counter atas semakin menguatnya arus islam radikal. Hal ini disebabkan karena Ahlussunnah Wal Jama'ah merupakan sistem teologi yang moderat, selain itu, Ahlusunnah Wal Jama'ah yang tertanam sebagai pengetahuan, pemahaman dan sikap merupakan modal penting untuk bersikap kritis dalam menghadapi dinamika sosial keagamaan yang semakin kompleks dalam rangka meperkukuh nasionalisme ${ }^{4}$. Kegiatan beribadah yang dilakukan sesuai dengan apa yang diajarkan oleh ajaran Aswaja yaitu

\footnotetext{
${ }^{2}$ Sudjana, "Penyuluhan Hukum dalam Upaya Peningkatan Kesadaran Hukum Berlalulintas Melalui Pemahaman Terhadap Isi Undang-Undang No. 22 Tahun 2009 Tentang Lalu Lintas dan Angkutan Jalan”, Jurnal Pendidikan Ilmu Sosial 25(2), 2016, hal 1.

${ }^{3}$ Fitrotun Nikmah, "Implementasi Konsep At Tawasuth Ahlusunnah Waljama'ah dalam Membangun Karakter Anak di Tingkat Sekolah Dasar (Studi Analisis Khittah Nahdlatul Ulama), Jurnal Tarbawi 15(1), 2018, hal. 86. https://doi.org/10.34001/tarbawi.v15i1.720

${ }^{4}$ Ahmad Rifa'i, Sucihatiningsih Dian WP \& Moh Yasir Alimi, "Pembentukan Karakter Nasionalisme Melalui Pembelajaran Pendidikan Aswaja pada Siswa Madrasah Aliyah Al Asror Semarang”, Journal of Education Social Studies 6(1), 2017, hal 9.
} 
mengutamakan sunnah Rasulullah, bukan hanya dalam kegiatan beribadah saja, akan tetapi dalam melakukan kegiatan sehari-hari, mereka juga mengacu pada apa yang diajarkan oleh Nahdlatul Ulama dan Aswaja termasuk dalam kehidupan berbangsa dan bernegara yang taat akan hukum.

Penelitian tentang kesadaran hukum ini berkaitan erat dengan penelitian Atang Hermawan Usman (2014) yang lebih fokus mengkaji kesadaran hukum masyarakat dan pemerintah sebagai faktor tegaknya negara hukum di Indonesia, hasil dari penelitian tersebut menjelasakan bahwa masih rendah dan menajdi sebab belum tegaknya pronsip-prisnsip negara hukum di Indonesia ${ }^{5}$. Penelitian tentang kesadaran hukum oleh Kamaruddin (2016) lebih fokus mengkaji tentang membangun kesadaran dan ketaatan hukum melalui pendekatan penegakan hukum. Penelitian tersebut menjelaskan bahwa keadaan hukum dalam arti peraturan perundang-undangan tidak akan mampu mengejar perubahan di dalam masyarakat yang begitu besar dan cepat akibat pembangunan yang berencana. Oleh karena itu, dalam melakukan penegakan hukum ( law enforcement) disegala bidang maka kesadaran dan ketaatan hukum harus senantiasa terbangun dan beriringan. Kelemahan selama ini dalam penegakan hukum karena tidak pernah berjalan secara simultan, akibatnya masih terjadi pelanggaran hukum dimana-mana. Dua hal ini menjadi kata kunci, bahwa dalam membangun kesadaran dan ketaatan hukum masyarakat perspektif law enforcement maka perlu dilaksanakan dari hulu sampai hilir oleh masyarakat. Karena sepanjang ini tidak dilakukan maka kita tidak bisa berharap banyak dari aspek hukum untuk perbaikan bangsa ini ke depan ${ }^{6}$.

Sedangkan penelitian Fitrotun Nikmah (2018) lebih banyak mengkaji tentang Implementasi Konsep At Tawasuth Ahlusunnah Waljama'ah dalam Membangun Karakter Anak di Tingkat Sekolah Dasar, penelitian tersebut hanya terbatas konsep at-Tawasuth Ahlus Sunnah Wal Jamaah dalam membangun karakter anak secara garis besar dapat dilakukan dalam berbagai aspek kehidupan

\footnotetext{
5 Atang Hermawan Usman, Op. Cit,. hal 52.

${ }^{6}$ Kamaruddin, "Membangun Kesadaran Dan Ketaatan Hukum Masyarakat Perspektif Law Enforcement”, Jurnal al Adl 9 (2), 2016, hal 143-157.
} 
sehari-hari, yaitu pada bidang akidah, pada bidang akhlak, pada bidang pergaulan antar golongan dan pada bidang kebudayaan. Penelitian ini belum mengkaji tentang membangun kesadaran hukum dalam bernegara ${ }^{7}$.

Aswaja bisa ditransformasikan dalam kehidupan sehari-hari dengan melakukan rekonstruksi terhadap penampilan NU, sehingga NU menjadi organisasi Islam terbesar di Indonesia bukan hanya dalam jumlah populasi, tetapi juga harus diupayakan menjadi organisasi Islam terbesar dalam kualitas, sehingga NU memiliki daya tarik dan daya tawar yang tinggi baik daya tawar politik maupun daya tawar sosial. Dengan kualitas yang terbina secara baik dan selalu dipertahankan, NU akan sangat diperhitungkan baik oleh pemerintah maupun masyarakat, termasuk masyarakat internasional ${ }^{8}$. Nahdlatul Ulama dalam peranannya yang begitu besar dalam memperjuangkan kemerdekaan Indonesia, mempertahankan keutuhan NKRI dapat dilihat atas latar belakang lahirnya ormas terbesar di dunia Nahdlatul Ulama (NU). Paling tidak ada tiga alasan besar yang melatarbelakangi lahirnya Nahdlatul Ulama 31 Januari 1926, yaitu Pertama, motif agama. Kedua, motif mempertahankan paham Ahlusunnah Wal Jama'ah, dan ketiga, motif nasionalisme ${ }^{9}$. Nahdlatul Ulama (NU), sebagai organisasi Islam terbesar di Indonesia ikut bertanggung jawab untuk memberikan kontribusi dalam mewujudkan cita-cita keadaban bangsa ${ }^{10}$.

Penelitian sebelumnya hanya sebatas mengkaji kesadaran hukum masyarakat dan pemerintah yang masih rendah, dan bagaimana upaya penegakan hukum sebagai upaya untuk meningkatkan kesadaran dan ketaatan hukum. Penelitian oleh Fitrotun Nikmah menkaji mengenai Ahlusunnah Waljama'ah tetapi dilakukan hanya sebatas untuk membentuk karakter anak. Melihat perkembangan zaman sekarang ini tentu dengan banyaknya pendapat terdahulu yang hanya memfokuskan

\footnotetext{
7 Fitrotun Nikmah, Op. Cit., hal 90.

${ }^{8}$ Mujamil Qomar, "Implementasi Aswaja dalam Perspektif NU di Tengah Kehidupan Masyarakat”, Jurnal Kontemplasi 2(1), 2014, hal.181.

${ }^{9}$ Amin Farih, "Nahdlatul Ulama (NU) dan Kontribusinya dalam Memperjuangkan Kemerdekaan dan Mempertahankan Negara Kesatuan Republik Indonesia (NKRI)”, Jurnal Penelitian Sosial Keagamaan 24(2), 2016, hal 252. DOI: http://dx.doi.org/10.21580/ws.24.2.969

${ }^{10}$ Masmuni Muhatma, "Paradigma Politik Nahdlatul Ulama (NU) dalam Bernegara”, Jurnal Dakwah dan Pengembangan Sosial Kemanusiaan 8(1), 2017, hal 32.
} 
pada masalah linier saja tidak dapat menghasilkan pemecahan masalah, solusi atau trobosan baru, terkait dengan penurunan kesadaran hukum berbangsa dan bernegara. berdasarkan beberapa uraian diatas menunjukkan bahwa kurangnya pandangan tentang luasnya fokus pembahasan materi yang dapat dijadikan sebagai konsepsi peningkatan sadar hukum berbangsa dan bernegara seperti menyandingkan upaya peningkatan sadar hukum berbangsa dan bernegara dengan perspektif ajaran islam.

Pentingnya memperluas cakupan pandangan mengenai sadar hukum berbangsa dan bernegara melalui perspektif ajaran Ahlusunnah Wal Jama'ah menjadikan penelitian ini lebih efektif dan terarah dalam menemukan konsepsinya. Melalui Nahdlatul Ulama dengan ajaran Ahlusunnah Wal Jama'ah penting guna meneguhkan paham kebangsaan dengan pancasila sebagai ideologi negara. Ideologisasi Pancasila di interpretasikan dengan Islam Nusantara yang menjadi jargon dalam setiap momen. Kemudian dijadikan pedoman atau landasan hukum berbangsa dan bernegara juga dalam upaya peningkatan sadar hukum di Indonesia. Adapun tujuan penelitian ini adalah untuk mengetahui upaya meningkatkan sadar hukum berbangsa dan bernegara ditinjau dari ajaran Ahlusunnah Wal Jama'ah serta perlunya meningkatkan sadar hukum dalam berbangsa dan bernegara ditinjau dari ajaran Ahlusunnah Wal Jama'ah.

\section{B. Perumusan Masalah}

Berdasarkan uraian diatas dapat dirumuskan beberapa masalah, diantaranya Bagaimana upaya untuk meningkatkan sadar hukum dalam berbangsa dan bernegara ditinjau dari ajaran Ahlusunnah Wal Jama'ah? dan Mengapa perlu meningkatkan sadar hukum dalam berbangsa dan bernegara ditinjau dari ajaran Ahlusunnah Wal Jama'ah?

\section{Landasan Teoritis}

\section{a. Teori Kesadaran Hukum}

Dalam ilmu hukum terdapat rumusan tentang kesadaran hukum, dimana kesadaran hukum merupakan satu-sartnya sumber aturan yang mengikat, keyakinan hukum dalam masyarakat merupakan kesadaran hukum individu, kesadaran hukum 
merupakan unsur penting selain ketaatan hukum yang menetukan efektifitas pelaksanaan hukum dalam masyarakat.

Kesadaran hukum merupakan kesadaran nilai-nilai dan konsepsi-konsepsi abstrak yang terdapat dalam diri manusia, tentang keserasian antara ketertiban dan ketentraman yang dikehendaki atau sepantasnya. ${ }^{11}$ Kesadaran hukum memiliki beberapa konsep, salah satu diantaranya adalah konsep kebudayaan hukum, konsep ini mengandung ajaran-ajaran tentang kesadaran hukum yang diangap sebagai penengah antara hukum dan prilaku manusia, baik secara individu maupun secara kolektif.

Kemajuan suatu bangsa dapat dilihat dari tingkat kesadaran hukum masyarakat, semakin tinggi tingkat kesadarn hukum masyarakat maka kehidupan akan semakin tertib, sebaliknya apabila kesadaran hukum masyarakat rendah maka yang berlaku adalah hukum rimba dimana yang kuat yang menang. Hal ini didasarkan pada kesadaran hukum masyarakat, dimana kesadaran hukum sendiri belum menjamin bahwa masyarakat akan melakukanya, mengingat setiap diri manusia memiliki kepentingan, masyarakat yang tau tentang hukum tanpa dilaksanakan termasuk dalam kategori kesadaranya masih rendah, sedangkan kesadaran hukum yang diketahui serta diamalkan atau dilaksanakan termasuk tinggi.

\section{b. Kepatuhan Hukum}

Kepatuhan hukum merupakan ketaatan pada suatu aturan, terkait ini adalah hukum aktif yang tertulis atau peraturan perundang-undangan yang memiliki berbagai macam kekuasaan maupun kekuatan, yang mendasari kepatuhan dan ketaatan hukum adalah kesadaran akan suatu aturan. Dalam konteks kepatuhan hukum teerdapat sanksi positif dan negatif, sedangkan terdapat beberapa faktor yang mempengaruhi masyarakat untuk mematuhi suatu peraturan, yaitu compliance, identification, internalization.

\footnotetext{
${ }^{11}$ Soerjono Soekanto, Sosiologi Suatu Pengantar, (Raja Grafindo Persada : Jakarta, 2014), hal. 215 .
} 
Kepatuhan merupakan sikap aktif yang berdasarkan pada motivasi setelah mendapatkan suatu pengetahuan, dengan memiliki suatu pengetahuan maka manusia akan tergerak untuk menentukan sikap dan bertindak. Sehingga yang mendasari kepatuhan adalah pendidikan, kebiasaan, kemanfaatan, dan identifikasi kelompok, dengan berdasarkan inilah akan membuat manusia untuk patuh terhadap apa yang dia ketahua, terkait hal ini adalah kepatuhan terhadap aturan yang berlaku atau hukum.

\section{PEMBAHASAN}

\section{A. Upaya Untuk Meningkatkan Sadar Hukum Dalam Berbangsa Dan Bernegara Ditinjau Dari Ajaran Ahlusunnah Wal Jama'ah.}

Sebelum masuk dalam pembahasan tentang upaya meningkatkan sadar hukum yang lebih mendalam, tentunya perlu memahami apa makna hukum sebenarnya, menurut J.C.T. Simorangkir dan Woerjono Sastropranoto, hukum itu ialah "peraturan-peraturan yang bersifat memaksa, menentukan tingkah laku manusia dalam lingkungan masyarakat yang dibuat oleh badan resmi berwajib, pelanggaran mana terhadap peraturan-peraturan tersebut berakibatkan diambilya tindakan, yaitu dengan hukuman tertentu". ${ }^{12}$

Ketentuan yuridis tentang penyuluhan hukum diatur dalam Peraturan Menteri Hukum dan HAM RI Nomor : M-01.PR.08.10 Tahun 2007 tentang Perubahan atas Peraturan Menteri Hukum dan Hak Asasi Manusia RI Nomor : M01.PR.08.10 Tahun 2006 tentang Pola Penyuluhan Hukum. Latar belakang keluarnya peraturan menteri tersebut adalah dalam rangka mengembangkan budaya hukum di semua lapisan masyarakat agar dapat tercipta kesadaran dan kepatuhan hukum demi tegaknya supremasi hukum di Negara Kesatuan Republik Indonesia, perlu dilakukan penyuluhan hukum secara nasional dan agar pelaksanaan penyuluhan hukum secara nasional dapat berjalan secara tertib, terarah, dan terpadu, perlu didasarkan pada pola penyuluhan hukum ${ }^{13}$. Sedangkan Kesadaran hukum

${ }^{12}$ C.S.T. Kansil, Pengantar Ilmu Hukum, (Balai Pustaka Jakarta, 2002), hal. 8.

${ }^{13}$ Sudjana, Op. Cit., $\quad$ hal. 3. 
masyarakat adalah nilai yang hidup dalam masyarakat dalam bentuk pemahaman dan ketaatan atau kepatuhan masyarakat terhadap hukum yang berlaku.

Kesadaran hukum adalah kesadaran diri sendiri tanpa paksaan, tekanan, atau perintah dari luar untuk tunduk pada hukum yang berlaku, berjalannya kesadaran hukum di masyarakat maka hukum tidak perlu menjatuhkan sanksi. Sanksi hanya dijatuhkan pada warga yang benar-benar terbukti melanggar hukum, hukum berisi perintah dan larangan, Hukum menunjukan mana perbuatan yang bertentangan dengan hukum yang bila dilakukan akan mendapat ancaman berupa sanksi, terhadap perbuatan yang bertentangan dengan hukum tentu saja dianggap melanggar hukum sehingga mendapat ancaman hukuman ${ }^{14}$.

Terdapat empat indikator kesadaran hukum yaitu pengetahuan hukum, pemahaman hukum, sikap hukum, pola prilaku hukum, Setiap indikator menunjuk pada tingkat kesadaran hukum tertentu mulai dari yang terendah sampai dengan yang tertinggi ${ }^{15}$ :

1) Pengetahuan hukum adalah pengetahuan seseorang mengenai beberapa perilaku tertentu yang diatur oleh hukum. Pengetahuan tersebut berkaitan dengan prilaku yang dilarang ataupun prilaku yang diperbolehkan oleh hukum. Seperti yang terlihat di dalam masyarakat bahwa pada umumnya seseorang mengetahui bahwa membunuh, mencuri, dan seterusnya dilarang oleh hukum. Pengetahuan hukum tersebut erat kaitannya dengan asumsi bahwa masyarakat dianggap mengetahui isi suatu peraturan manakala peraturan tersebut telah diundangkan.

2) Pemahaman hukum mengenai isi peraturan dari hukum tertentu. Dengan lain perkataan pemahaman hukum adalah suatu pengertian terhadap isi dan tujuan dari suatu peratuan dalam suatu hukum tertentu, tertulis maupun tidak tertulis, serta manfaatnya bagi pihak-pihak yang kehidupannya tidak disyaratkan seseorang harus terlebih dahulu mengetahui adanya suatu aturan tertulis

\footnotetext{
${ }^{14}$ Ellya Rosana, "Kepatuhan Hukum Sebagai Wujug Kesadaran Hukum Masyarakat”, Jurnal TAPIs 10(1), 2014, hal 3. DOI: https://doi.org/10.24042/tps.v10i1.1600

${ }^{15}$ Soerjono Soekanto, (Beberapa permasalahan hukum dalam kerangka pembangunan di Indonesia, (Yayasan Penerbit UI : Jakarta, 1982), hal. 140.
} 
3) Sikap hukum adalah suatu kecenderungan untuk menerima hukum karena adanya penghargaan terhadap hukum sebagai sesuatu yang bermanfaat atau menguntungkan jika hukum itu ditaati.

4) Perilaku hukum, Pola perilaku hukum merupakan hal utama dalam kesadaran hukum karena disini dapat dilihat apakah suatu peraturan berlaku atau tidak dalam masyarakat.

Kesadaran hukum memiliki hubungan dengan aspek-aspek kognitif dan perasaan yang biasanya dianggap sebagai faktor yang mempengaruhi kesadaran hukum tersebut, pola-pola perilaku manusia dalam kehidupan bermasyarakat serta berkembangnya ajaran kesadaran hukum yang menitikberatkan pada nilai-nilai yang berlaku pada masyarakat. Sistem nilai-nilai akan menghasilkan acuan-acuan untuk berproses yang bersifat psikologis, antara lain pola-pola berfikir yang menentukan sikap mental manusia, sikap mental yang pada hakikatnya merupakan kecenderungan untuk bertingkah laku, membentuk pola-pola perilaku maupun kaidah-kaidah, dalam aspek psikologis ini dominan dipengaruhi oleh pola berfikir yang dipengaruhi oleh ajaran agama atau kepercayaan yang dianutnya sebagai pedoman hidup. Dalam empat faktor diatas dapat dikaitkan dengan ajaran islam, apabila keimanan dan ketaqwaan kepada Allah lebih tinggi, maka tingkat kesadaran hukumnya akan lebih tinngi daripada seseorang yang memiliki keimanan dan ketaqwaan yang kurang.

Ada beberapa penyebab masyarakat itu melanggar hukum karena alasan bahwa setiap manusia mempunyai kebutuhan yang berbeda-beda satu dengan yang lainnya dan untuk memenuhi kebutuhan hidupnya tersebut manusia akan melakukan segala cara. Mereka yang melanggar hukum juga karena beberapa hal, yaitu melanggar hukum karena memang tidak tahu hukum, Sebenarnya tidak ada manusia yang tidak tahu hukum. Hanya saja, di Indonesia banyak sekali undangundang yang telah dibuat pemerintah dan sangat disayangkan bahwa tidak semua undang-undang tersebut menyentuh seluruh lapisan masyarakat, banyak pula masyarakat yang tidak tau isi dari undang -undang tersebut dan sanksi apa yang dikenakan bagi para pelanggarnya. Juga karena Manusia melanggar hukum karena merasa punya kekuasaan atau materi berlebih, Banyak orang yang mempunyai 
kekuasaan atau jabatan yang tinggi merasa hal itu adalah segala-galanya sehingga tidak mempedulikan peraturan yang berlaku. Padahal dalam undang-undang dijelaskan bahwa setiap orang mempunyai kedudukan yang sama dihadapan hukum. Sehingga perlu adanya perhatian khusus mengenai perkembangan kesadaran hukum yang kemudian dapat di atasi menggunakan aspek yang lebih halus namun sangat menentukan, yaitu agama. Sebagai negara yang dominan penduduknya menganut agama islam dan berpegang teguh pada ajaran Ahlusunnah Wal Jama'ah, Negara Indonesia harusnya tentu bisa membuat atmosfer kehidupan berbangsa dan bernegara dengan lebih aman dan tentram.

Ahlusunnah Wal Jama'ah menjadikan negara sebagai sarana atau wadah untuk menjamin, melayani, melindungi dan mengarahkan seluruh yang ada di dalamnya, baik warga negara, keutuhan wilayah, termasuk keseluruhan harta kekayaan yang terdapat dalam wilayah negara tersebut. Ahlusunnah Wal Jama'ah juga menjadi pedoman untuk mempertahankan kesetabilan pemerintahan, serta menjaga kedaulatan dan menjamin kesejahteraan segenap warga negara dengan memberikan arahan kepada seluruh lapisan warga negara untuk meningkatkan kesadaran hukum bernegara dan tetap menjunjung tinggi hukum yang berlaku di Indonesia.

Untuk mencapai peningkatan budaya hukum dan membentuk kesadaran hukum masyarakat, upaya penyuluhan hukum harus menetapkan arah kebijakan ${ }^{16}$ : 1) Melakukan edukasi dan pembudayaan hukum secara umum ditujukan kepada seluruh masyarakat. Bahwa banyaknya pelanggaran hukum yang terjadi dikarenakan lemahnya diseminasi dan penyuluhan hukum yang merupakan bagian dari tanggung jawab penyelenggara negara dan aparat penegak hukum.

2) Meningkatkan penggunaan media komunikasi yang lebih modern dalam pelaksanaan penyuluhan hukum yang dapat menunjang percepatan penyebaran, pengetahuan, pemahaman, dan penghayatan hukum.

${ }^{16}$ Sudjana, Op. Cit., $\quad$ hal. 3-4. 
3) Meningkatkan koordinasi dalam melaksanakan sosialisasi hukum dengan memanfaatkan partisipasi masyarakat aktif, media elektronik amupun non elektronik dan juga dengan memanfaatkan teknologi informasi.

4) Meningkatkan dan memperkaya metode pengembangan dan penyuluhan hukum untuk meningkatkan kesadaran hukum masyarakat dan hak asasi manusia secara terus menerus.

5) Memanfaatkan segala bentuk kampanye hukum baik langsung maupun tidak langsung, dengan menciptakan slogan-slogan hukum yang melekat di hati masyarakat sehingga masyarakat tergerak dengan sendirinya untuk meningkatkan budaya hukum.

6) Meningkatkan profesionalisme dan kemampuan tenaga penyuluh hukum baik dari substansi hukum, sosiologi serta pengenalan perilaku masyarakat setempat, sehingga komunikasi dalam menyampaikan materi hukum yang disuluh dapat lebih tepat, dipahami, diterima dengan baik oleh masyarakat.

7) Melalui kemampuan dan profesionalisme dalam melakukan penyuluhan hukum, agar pesan yang disampaikan kepada masyarakat tercapai dan diterima secara baik, maka harus melakukan langkah cerdas dalam penyuluhan hukum dengan memberikan rasa percaya masyarakat kepada tenaga penyuluh.

8) Law enforcement harus dibarengi dengan upaya preventif dalam bentuk sosialisasi produk- produk hukum karena hukum juga harus memberikan perlindungan kepada rakyat untuk memperoleh keadilan bukan untuk menyengsarakan. Oleh karena itu penyuluhan hukum harus mendapatkan perhatian yang serius.

\section{B. Perlunya Meningkatkan Sadar Hukum Dalam Berbangsa Dan Bernegara Ditinjau Dari Ajaran Ahlusunnah Wal Jama'ah.}

Untuk dapat mengambil langkah-langkah guna mengatasi menurunnya kesadaran hukum masyarakat, perlu kiranya diketahui apakah kiranya yang dapat menjadi sebab-sebabnya. Menurunnya kesadaran hukum masyarakat itu merupakan gejala perubahan dalam masyarakat yaitu perubahan sosial. Salah satu sebab 
perubahan sosial menurut Arnold M Rose dalam Soerjono Soekanto ${ }^{17}$ adalah kontak atau konflik antar kebudayaan. Besarnya arus parwisata yang mengalir ke Indonesia tidak sedikit pengaruhnya dalam merangsang perubahan-perubahan sosial. Pengaruh film terutama film luar negeri serta televisi, majalah atau bacaanbacaan lainnya dengan adegan - adegan atau cerita yang sadis tidak berperikemanusiaan atau asusila mempunyai peran penting dalam membantu menurunkan kesadaran hukum masyarakat.

Fungsi dari peningkatan kesadaran hukum adalah sebagai langkah pencegahan, langkah korektif, langkah pemeliharaan dan fungsi pengembangan. Pertama, sebagai langkah pencegahan (preventif), yakni mencegah timbulnya hakhak negatif dan destruktif yang dapat mengakibatkan kerugian bagi masyarakat. Kedua, sebagai langkah korektif, yakni berfungsi sebagai koreksi terhadap hal yang telah ada, sehingga apabila terdapat suatu hal yang melanggar hukum dapat mengurangi dampak ataupun menghilangkan hal tersebut. Ketiga, sebagai langkah pemeliharaan (presevatif), yakni memberikan dorongan untuk menumbuhkan semangat supaya berpartisipasi dalam pembangunan hukum sesuai dengan kemampuan dan kedudukannya masing-masing. Keempat, sebagai fungsi pengembangan (developmental), yakni memberikan dorongan dan masukan terhadap suatu hal agar masyarakat dapat lebih mandiri dan tidak tergantung ataupun mengandalkan pihak lain.

Sedangkan, dalam pandangan Ahlusunnah Wal Jama'ah, melalui organisasi kemasyarakatan yang dikenal dengan Nahdlatul Ulama', ia menjadi bagian yang tidak terpisahkan dari keseluruhan bangsa Indonesia, Nahdlatul Ulama senantiasa menyatukan diri dengan perjuangan Nasional Bangsa Indonesia dalam proses kemerdekaan, penyusunan Undang-Undang Dasar 1945 bahkan dalam mengawal tegaknya hukum yang ada di negara Indonesia. Nahdlatul Ulama' dan segenap warganya selalu aktif mengambil bagian dalam pembangunan bangsa menuju masyarakat adil dan makmur yang diridhai Allah SWT. Oleh karennya, setiap

17 Soerdjono Soekanto, Kesadaran Hukum dan Kepatuhan Hukum, (Rajawali : Jakarta, 1982), hal. 35 . 
warga nahdliyin harus menjadi warga negara yang senantiasa menjunjung tinggi Pancasila dan Undang-Undang Dasar 1945 sebagai landasan dasar hukum yang berkembang di Indonesia.

Pemerintah Indonesia, ulama, dan organisasi masa Islam memiliki tanggungjawab untuk memelihara faham Aswaja, doktrin Aswaja dan ideologi Pancasila memiliki watak yang sama, yaitu moderasi. Pancasila itu moderasi antar faham, aliran, golongan, ras. Aswaja juga sebuah faham moderat dalam Islam. Ia merupakan jalan tengah antara radikalisme dan liberalisme. Aswaja menghargai pluralitas, perbedaan termasuk beda agama dan keyakinan, karena wahyu dan pengalaman sejarah menuntunnya untuk menghargai perbedaan tersebut ${ }^{18}$.

Nahdlatul Ulama yang berasaskan Ahlusunnah Wal Jama'ah senantiasa memegang teguh prinsip persaudaraan (ukhuwwah), toleransi (at-tasamuh), kebersamaan dan hidup berdampingan baik dengan sesame warga Negara yang mempunyai keyakinan/agama lain untuk bersama-sama mewujudkan cita-cita persatuan dan kesatuan bangsa yang kokoh dan dinamis ${ }^{19}$. Nahdlatul Ulama berusaha secara sadar untuk menciptakan warga negara yang menyadari akan hak dan kewajibannya terhadap bangsa dan negara, serta warga nahdliyin harus menggunakan hak-hak nya, seperti hak politiknya harus dilakukan secara bertanggung jawab, sehingga dengan demikian dapat ditumbuhkan sikap hidup yang demokratis, konstitusional, taat hukum dan mampu mengembangkan mekanisme musyawarah dan mufakat dalam memecahkan masalah yang dihadapi bersama oleh Bangsa Indonesia.

Dalam pengamalan bersaman NU dan Ahlusunnah Wal Jama'ah, gerakan meningkatkan kesadaran moral nasional perlu di bangkitkan lagi demi pemulihan kembali kasadaran hukum, hidup bermoral, beradab, bermartabat, yang pada akhirnya berusaha mengembalikan fungsi akal sehat dan hati nurani bangsa secara

\footnotetext{
${ }^{18}$ Ahmad Syafi'I Mufid, "Paham Ahlusunnah Wal Jama'ah dan Tantangan Kontemporer dalam Pemikiran dan Gerakan Islam di Indonesia”, Jurnal Multikultural \& Multireligius 12(3), 2013, hal 6.

${ }^{19}$ Tim Aswaja NU Center PWNU Jawa Timur, Khazanah Aswaja, (Aswaja NU Center PWNU ;Jawa Timur, : Surabaya, 2016), hal. 454
} 
otonom agar kembali menuju jalan yang lurus. Hal ini disebabkan selama ini perjalanan bangsa terjebak pada hal-hal yang menyebabkan rakyat hanya dijadikan alat politik kekuasaan. Sebagai akibatnya, kehidupan spiritualitas kurang dikedepankan dalam kehudupan bernegara. Tak jarang bahkan agama digunakan sebagai jalan pintas bahkan alat politik untuk meraih posisi kekuasaan dengan mengorbankan kepentingan masyarakat bersama serta mengesampingkan hukum dan aturan yang mengikatnya.

Maka untuk pentingnya meningkatkan kesadaran hukum berbangsa dan bernegara, diharapkan NU yang berpegang teguh pada ajaran Ahlusunnah Wal Jama'ah mampu memainkan perannya menjadi kekuatan penyeimbang untuk menghindari ancaman serius bagi keberlangsungan negara Indonesia, yang selanjutnya peran NU tetap bisa menjadi garda terdepan dan mengajak semua komponen bangsa menajdi agen perubahan yang mampu menjadi pilar-pilar penyangga kehidupan bangsa dengan dilandasi kepatuhan terhadap hukum berbangsa dan bernegara.

\section{PENUTUP}

Upaya untuk mencapai peningkatan kesadaran hukum masyarakat dapat dilakukan dengan edukasi dan pembudayaan hukum secara umum ditujukan kepada seluruh masyarakat, Meningkatkan penggunaan media komunikasi yang lebih modern, Meningkatkan koordinasi dalam melaksanakan sosialisasi hukum, Meningkatkan dan memperkaya metode pengembangan dan penyuluhan hukum, Memanfaatkan segala bentuk kampanye hukum baik langsung maupun tidak langsung, Meningkatkan profesionalisme dan kemampuan tenaga penyuluh hukum baik dari substansi hukum, sosiologi serta pengenalan perilaku masyarakat setempat, Melalui kemampuan dan profesionalisme dalam melakukan penyuluhan hukum, agar pesan yang disampaikan kepada masyarakat tercapai dan diterima secara baik, Law enforcement harus dibarengi dengan upaya preventif dalam bentuk sosialisasi produk- produk hukum. Fungsi dari peningkatan kesadaran hukum adalah sebagai langkah pencegahan, langkah korektif, langkah pemeliharaan dan fungsi pengembangan. Nahdlatul Ulama yang berasaskan Ahlusunnah Wal Jama'ah senantiasa memegang teguh prinsip persaudaraan (ukhuwwah), toleransi 
(at-tasamuh), sehingga gerakan mingkatkan kesadaran moral nasional perlu di bangkitkan lagi demi pemulihan kembali kasadaran hukum, hidup bermoral, beradab, bermartabat, yang pada akhirnya berusaha mengembalikan fungsi akal sehat dan hati nurani bangsa secara otonom agar kembali menuju jalan yang lurus. Sehingga penting bagi warganegara yang berlandasakan Pancasila, serta mengamalkan nilai keimanan kepada Allah SWT untuk meningkatkan kesadaran hukum berbangsa dan bernegara dengan tetap berpedoman pada ajaran Ahlusunnah Wal Jama'ah agar tercapainya kehidupan yang sejahtera dan selamat di dunia maupun di akhirat. Serta bisa dikatakan individu yang sadar hukum sama halnya mencintai tanah airnya, hal tersebut selaras dengan apa yang diajarkan oleh NU dalam berbangsa dan bernegara yaitu Hubbul Wathan Minal Iman.

\section{DAFTAR PUSTAKA}

\section{Buku}

Kansil, C.S.T. Pengantar Ilmu Hukum, Balai Pustaka, 2002, Jakarta.

Soekanto, Soerjono. Beberapa Permasalahan Hukum Dalam Kerangka Pembangunan di Indonesia, Yayasan Penerbit UI, 1982, Jakarta.

1982, Jakarta. , Kesadaran Hukum dan Kepatuhan Hukum, Rajawali, 2014, Jakarta. , Sosiologi Suatu Pengantar, Raja Grafindo Persada,

Tim Aswaja NU Center PWNU Jawa Timur, Khazanah Aswaja, Aswaja NU Center PWNU Jawa Timur, 2016, Jawa Timur.

\section{Jurnal}

Ahmad Rifa'i, Sucihatiningsih Dian WP \& Moh Yasir Alimi, "Pembentukan Karakter Nasionalisme Melalui Pembelajaran Pendidikan Aswaja pada Siswa Madrasah Aliyah Al Asror Semarang”, Journal of Education Social Studies 6(1), 2017.

Ahmad Syafi'I Mufid, "Paham Ahlusunnah Wal Jama'ah dan Tantangan Kontemporer dalam Pemikiran dan Gerakan Islam di Indonesia”, Jurnal Multikultural \& Multireligius 12(3), 2013.

Amin Farih, "Nahdlatul Ulama (NU) dan Kontribusinya dalam Memperjuangkan Kemerdekaan dan Mempertahankan Negara Kesatuan Republik Indonesia (NKRI)", Jurnal Penelitian Sosial Keagamaan 24(2), 2016, hal 252. DOI: http://dx.doi.org/10.21580/ws.24.2.969

Atang Hermawan Usman, "Kesadaran Hukum Masyarakat dan Pemerintah Sebagai Faktor Tegaknya Negara Hukum di Indonesia”, Jurnal Wawasan Hukum 30(1), 2014. DOI: http://dx.doi.org/10.25072/jwy.v30i1.74 
Ellya Rosana, "Kepatuhan Hukum Sebagai Wujug Kesadaran Hukum Masyarakat”, Jurnal TAPIs 10(1), 2014, hal 3. DOI: https://doi.org/10.24042/tps.v10i1.1600

Fitrotun Nikmah, "Implementasi Konsep At Tawasuth Ahlusunnah Waljama'ah dalam Membangun Karakter Anak di Tingkat Sekolah Dasar (Studi Analisis Khittah Nahdlatul Ulama), Jurnal Tarbawi Vol.15 No. 1 Januari-Juni 2018, Magister Pendidikan Dasar Universitas Muria Kudus, 2018, Kudus.

Kamaruddin, "Membangun Kesadaran Dan Ketaatan Hukum Masyarakat Perspektif Law Enforcement”, Jurnal Al Adl 9(2), 2016. http://dx.doi.org/10.31332/aladl.v9i2.683

Masmuni Muhatma, "Paradigma Politik Nahdlatul Ulama (NU) dalam Bernegara”, Jurnal Dakwah dan Pengembangan Sosial Kemanusiaan 8(1), 2017.

Mujamil Qomar, "Implementasi Aswaja dalam Perspektif NU di Tengah Kehidupan Masyarakat”, Jurnal Kontemplasi 2(1), 2014.

Sudjana, "Penyuluhan Hukum dalam Upaya Peningkatan Kesadaran Hukum Berlalulintas Melalui Pemahaman Terhadap Isi Undang-Undang No. 22 Tahun 2009 Tentang Lalu Lintas dan Angkutan Jalan”. Jurnal Pendidikan Ilmu Sosial 25(2), 2016.

\section{Undang-Undang}

Undang-Undang Dasar Negara Republik Indonesia Tahun 1945.

Peraturan Menteri Hukum dan HAM RI Nomor:M-01.PR.08.10 Tahun 2007 tentang Perubahan atas Peraturan Menteri Hukum dan Hak Asasi Manusia RI Nomor:M01.PR.08.10 Tahun 2006 tentang Pola Penyuluhan Hukum 